\title{
Marine actinomycete crude extracts with potent TRAIL- resistance overcoming activity against breast cancer cells
}

\author{
MOHAMMED I.Y. ELMALLAH ${ }^{1,2}$, OLIVIER MICHEAU ${ }^{3,4}$, MENNAT ALLAH G. EID ${ }^{1}$, \\ ALI M.S. HEBISHY ${ }^{1,2}$ and MOHAMED S. ABDELFATTAH ${ }^{1,2}$ \\ ${ }^{1}$ Marine Natural Products Unit (MNPRU), Faculty of Science, Helwan University; ${ }^{2}$ Chemistry Department, \\ Faculty of Science, Helwan University, 11795 Ain Helwan, Cairo, Egypt; ${ }^{3}$ LNC, INSERM, UMR1231; \\ ${ }^{4}$ UFR Science de santé, Université de Bourgogne Franche-Comté, F-21079 Dijon, France
}

Received October 3, 2016; Accepted March 16, 2017

DOI: $10.3892 /$ or.2017.5595

\begin{abstract}
Tumor necrosis factor-related apoptosis-inducing ligand (TRAIL) is a promising anticancer agent, as it can kill tumor cells selectively. In our search of bioactive natural products to overcome TRAIL-resistance, we isolated 47 actinomycete strains from different sediments and seawater samples collected from the Red Sea coast in Egypt and found four crude extracts (EGY1, EGY3, EGY24 and EGY34) displaying TRAIL sensitizing activity in the resistant breast cancer cell line MDA-MB-231. None of these crude extracts exhibited cytotoxic effect on normal mouse embryonic fibroblasts (MEF), with the exception of EGY34. Analysis of the signaling pathways underlying the sensitization of MDA-MB-231 cells to TRAIL-induced apoptosis, by western blotting, revealed that all crude extracts facilitated initiator caspase-8/-10 activation upon TRAIL stimulation, but that in addition, EGY3 and EGY34, alone, induced strong ER-stress activation, with the appearance of $\mathrm{BiP}$ in the cytosolic extracts. Our results pave the way to the discovery and the development of marine-derived drugs for cancer therapy.
\end{abstract}

\section{Introduction}

Tumor necrosis factor-related apoptosis-inducing ligand (TRAIL) is a type II transmembrane protein belonging to the tumor necrosis factor (TNF) superfamily. It is expressed on the surface of certain immune cells including T-lymphocytes and natural killer (NK) cells. TRAIL plays a central role in immune surveillance. Owing to the fact that it induces selective apoptosis in tumor cells, but not normal cells, TRAIL has been considered as a promising therapeutic anticancer agent $(1,2)$.

Correspondence to: Dr Mohamed S. Abdelfattah, Marine Natural Products Unit (MNPRU), Faculty of Science, Helwan University, 11795 Ain Helwan, Cairo, Egypt

E-mail: mabdelfattah@science.helwan.edu.eg

Key words: marine actinomycetes, MDA-MB-231 breast cancer cells, apoptosis, TRAIL-resistance
The apoptotic signaling pathway regulated by TRAIL is initiated by its binding to agonist death receptors, namely DR4/TRAIL-R1 and DR5/TRAIL-R2. Oligomerization of these receptors allow the recruitment of the adaptor protein Fas-associated death domain (FADD), which subsequently stimulates the formation of death-inducing signaling complex (DISC) through recruitment of the pro-caspase- $8(3,4)$. Activation of pro-caspase- 8 within the DISC, by proximity, activates either a cascade of caspase-cleavage leading to activation of caspase-3, -6 , and -7 (extrinsic pathway) or stimulates the mitochondrial pathway (intrinsic pathway) via cleavage of the $\mathrm{BH} 3$-interacting domain death agonist (Bid) to truncated Bid (tBid)/caspase-3, inducing an irreversible cell death (5). Despite potent anticancer activity, resistance to TRAIL-induced apoptosis has been reported in several malignant cells (6-12). The mechanism by which the tumor cell gains resistance to TRAIL mainly include i) a deficiency of DR expression, ii) overexpression of anti-apoptotic proteins, or iii) competition of the decoy receptors (DcR1/TRAIL-R3 and DcR2/TRAIL-R4) for TRAIL binding (13-15). However, conventional or non-conventional chemotherapy can restore TRAIL sensitivity (16-18).

Marine environment encompasses a great variety of microorganisms living in extreme conditions such as high salinity, pressure and temperature. These organisms were reported to produce unique and structurally novel secondary metabolites allowing their survival in such conditions (19). Marine actinomycetes are considered as an unexplored source of biologically active secondary metabolites including antibacterial, anti-fungal, anti-malarial, anti-inflammatory, and antitumor (20-25). Several natural products derived from terrestrial and marine actinomycetes were investigated for their TRAIL-resistance overcoming activities and the molecular mechanisms that trigger the induction of apoptosis were determined (25-30). In this study, we investigated TRAILresistance overcoming activity of several crude extracts of marine actinomycetes isolated from the Red Sea. In TRAILresistant MDA-MB-231 breast cancer cells, four crude extracts obtained from Streptomyces sp. (EGY1, EGY3, EGY24, and EGY34) showed selective TRAIL synergistic activity, but had no effect on the normal mouse embryonic fibroblast (MEF). Analyzing the signaling pathways triggered by the 
co-treatment indicate that these crude extracts possibly act through two distinct mechanisms; either through i) activation of caspase- 8 and -10 pathways or ii) induction of ER-stress via stimulation of ER-stress sensors, BiP. Our results are expected to provide new insight into the development of lead marinederived structures against cancer.

\section{Materials and methods}

Collection of samples. Thirty samples of sediments, sea water and sands were collected from different parts of Sharm El-Sheikh, South Sinai, Egypt. The collected samples were kept in $50 \mathrm{ml}$ sterile Falcon tubes and preserved in refrigerator for further study.

Isolation of actinomycetes. Wet sediment/sand (1 g) was dispersed in $9 \mathrm{ml}$ of sterilized water. The samples were vortexed for $2 \mathrm{~min}$ and subjected to heat treatment in a water bath at $60^{\circ} \mathrm{C}$ for $10 \mathrm{~min}$ to eliminate non-sporulating bacteria. Following serial dilution $\left(10^{-1}, 10^{-2}\right.$ and $\left.10^{-3}\right)$ of the suspension with sterile water, a $100 \mu l$ aliquot was spread on humic acid-vitamin agar (31): humic acid (1.0 g/l), $\mathrm{Na}_{2} \mathrm{HPO}_{4}(0.5 \mathrm{~g} / \mathrm{l})$, $\mathrm{KCl}(1.71 \mathrm{~g} / \mathrm{l}), \mathrm{MgSO}_{4} .7 \mathrm{H}_{2} \mathrm{O}(0.05 \mathrm{~g} / \mathrm{l}), \mathrm{FeSO}_{4} .7 \mathrm{H}_{2} \mathrm{O}(0.01 \mathrm{~g} / \mathrm{l})$, $\mathrm{CaCO}_{3}(0.02 \mathrm{~g} / \mathrm{l})$, vitamin mixture $(1.0 \mathrm{ml})$ and agar $(18.0 \mathrm{~g} / \mathrm{l})$; and starch-casein agar (32): soluble starch (10.0 g/l), casein $(0.3 \mathrm{~g} / \mathrm{l}), \mathrm{K}_{2} \mathrm{HPO}_{4}(2.0 \mathrm{~g} / \mathrm{l}), \mathrm{KNO}_{3}(2.0 \mathrm{~g} / \mathrm{l}), \mathrm{NaCl}(2.0 \mathrm{~g} / \mathrm{l})$, $\mathrm{MgSO}_{4} .7 \mathrm{H}_{2} \mathrm{O}(0.05 \mathrm{~g} / \mathrm{l}), \mathrm{CaCO}_{3}(0.02 \mathrm{~g} / \mathrm{l}), \mathrm{FeSO}_{4} .7 \mathrm{H}_{2} \mathrm{O}$ $(0.01 \mathrm{~g} / \mathrm{l})$, agar $(15 \mathrm{~g} / \mathrm{l})$. All media were prepared in $50 \%$ filtered Red Sea water and supplemented with nalidixic acid $\left(75 \mu \mathrm{g} \mathrm{ml}^{-1}\right)$ and cycloheximide $\left(50 \mu \mathrm{g} \mathrm{ml}^{-1}\right)$ as antibacterial and antifungal agents, respectively. The plates were incubated at $30^{\circ} \mathrm{C}$ for 7-30 days until the colonies appeared. Forty-seven actinomycete strains were picked up, subsequently spread on Waksman agar plates and labeled with the code numbers EGY1 to EGY47. Characterizations of the isolated strains were carried by morphological methods (33) and on the basis of 16S rRNA partial gene sequences (34).

Fermentation and preparation of crude extracts. To prepare the cultures, chunks of well grown agar plate of each strain were used to inoculate $2 \times 100 \mathrm{~cm}^{3}$ Erlenmeyer flasks each containing $100 \mathrm{ml}$ of Waksman medium with $50 \%$ sea water. The Waksman liquid medium contains glucose $(2.0 \mathrm{~g} / 100 \mathrm{ml})$, meat extract $(0.5 \mathrm{~g} / 100 \mathrm{ml})$, peptone $(0.5 \mathrm{~g} / 100 \mathrm{ml})$, dried yeast $(0.3 \mathrm{~g} / 100 \mathrm{ml})$, $\mathrm{NaCl}(0.5 \mathrm{~g} / 100 \mathrm{ml})$ and $\mathrm{CaCO}_{3}(0.3 \mathrm{~g} / 100 \mathrm{ml})$. The cultures were grown at $28^{\circ} \mathrm{C}$ for 3-4 days with reciprocal shaking at 200 r.p.m. A library of crude extracts was constructed through a consecutive extraction of the culture broths of different strains with ethyl acetate. The cell pellets were extracted two times with methanol. The solvents from culture broth and mycelia were evaporated under vacuum, collected together in a small glass vial, and then stored at $-20^{\circ} \mathrm{C}$ for further use. Each vial took a serial number identical to the number of its own bacterial strain. Each crude extract was dissolved in dimethyl sulfoxide (DMSO) for further investigation.

Cell culture. The human TRAIL-resistant MDA-MB-231 breast cancer cell line was a kind gift of Dr Patrick Legembre (Rennes, France). Normal mouse embryonic fibroblast cell line (MEF) was obtained from the (ATCC-CF-1 SCRC 1040).
Monolayer cell cultures were grown in Dulbecco's modified Eagle's medium (DMEM) supplemented with $4.5 \mathrm{~g} / 1$ of glucose, $4 \mathrm{mmol} / \mathrm{l}$ of L-glutamine, and $10 \%$ heat-inactivated fetal calf serum (FCS).

Cell viability assay. MDA-MB-231 cells were seeded in 96-well plates $\left(4 \times 10^{4}\right.$ cells per well) in $100 \mu 1$ of DMEM medium. Cells were incubated at $37^{\circ} \mathrm{C}$ in a $5 \% \mathrm{CO}_{2}$ incubator for $24 \mathrm{~h}$. Crude extracts at different doses $(0.04,0.1,0.2,0.3$, 0.6 and $1.2 \mathrm{mg} / \mathrm{ml}$ ) were added to each well. After $24 \mathrm{~h}$ incubation, the culture media was removed and the cells were washed with $100 \mu \mathrm{l}$ PBS. Cells that remained attached were fixed by adding $100 \mu \mathrm{l}$ of $70 \%$ ethanol. The plate was then incubated at room temperature for $1 \mathrm{~h}$ to remove ethanol and $100 \mu \mathrm{l}$ of methylene blue dye was added. The plates were incubated at room temperature for $15 \mathrm{~min}$. To remove the excess of dye, the plate was washed three times with tap water and then dried for $2 \mathrm{~h}$ at $37^{\circ} \mathrm{C}$. Dye was eluted from the attached cells by adding $100 \mu \mathrm{l}$ of $0.1 \mathrm{M} \mathrm{HCl}$ in each well and then incubated for $5 \mathrm{~min}$ at room temperature. The developed blue color was measured using an ELISA reader at $630 \mathrm{~nm}$.

To investigate whether the crude extracts have a synergistic effect with TRAIL, MDA-MB-231 breast cancer cells were treated with the crude extracts at various concentrations $(0.04$, $0.1,0.2,0.3,0.6$ and $1.2 \mathrm{mg} / \mathrm{ml}$ ) for $24 \mathrm{~h}$, followed by stimulation with TRAIL at final concentration of $250 \mathrm{ng} / \mathrm{ml}$ for an additional $24 \mathrm{~h}$. Controls referred to wells containing only cells and medium with and without $10 \%$ DMSO.

Detection of apoptosis. The MDA-MB-231 cells $\left(1 \times 10^{5}\right.$ cells per well) were seeded in a 12-well plate, treated with different doses of crude extracts (EGY1, EGY3, EGY24, EGY34) and TRAIL $(250 \mathrm{ng} / \mathrm{ml})$ then incubated for $16 \mathrm{~h}$ at $37^{\circ} \mathrm{C}$. The cells were harvested by centrifugation and stained with Annexin V and propidium iodide (PI) according to the manufacturer's instructions (AbCys SA). Quantification of apoptosis-induced by the crude extracts with and without TRAIL was analyzed by flow cytometry using a FACScanto II flow cytometer (BD Becton-Dickinson).

Western blot analysis. Approximately $1 \times 10^{6}$ of the cells were seeded in 6-well plates, treated with the crude extracts, and then incubated for $24 \mathrm{~h}$. The cells were stimulated with TRAIL (250 ng/ml) and incubated for $24 \mathrm{~h}$. Afterwards, the cells were collected and lysed in lysis buffer (1\% NP-40, Tris- $\mathrm{HCl}, 3 \mathrm{M} \mathrm{NaCl}$, 5\% glycerol). The concentration of protein was determined by Bradford reagent (Bio-Rad, Marnes-la-Coquette, France). Proteins were resolved by electrophoresis on $12 \%$ sodium dodecyl sulfatepolyacrylamide gel and transferred by electro-blotting to polyvinylidene difluoride (PVDF) membranes (Bio-Rad). The membranes were incubated overnight with the following primary antibodies. Anti-TRAIL-R1 (cat\# AB16955) and TRAIL-R2 (cat\# AB16942) antibodies were purchased from Chemicon (Millipore, Molsheim, France), antibodies against caspase-3 (clone 8G10), caspase-8 (clone 5F7) and caspase-10 (clone 4C1) were all from Medical \& Biological Laboratories (Clinisciences, Montrouge, France). Anti-BIP (cat\# 3177) and CHOP (cat\# 2895) were obtained from Cell Signaling Technology (Ozyme, St. Quentin Yvelines, 
Table I. Cytotoxic effects of 21 marine actinomycete crude extracts with and without TRAIL $(250 \mathrm{ng} / \mathrm{ml})$ on TRAILresistant MDA-MB-231 breast cancer cell line.

\begin{tabular}{|c|c|c|c|}
\hline \multirow[b]{2}{*}{$\begin{array}{l}\text { Crude extract } \\
(0.1 \mathrm{mg} / \mathrm{ml})\end{array}$} & \multicolumn{3}{|c|}{ Cell viability (\%) } \\
\hline & $\begin{array}{l}\text {-/- TRAIL } \\
(0 \mathrm{ng} / \mathrm{ml})\end{array}$ & $\begin{array}{l}+/+ \text { TRAIL } \\
(250 \mathrm{ng} / \mathrm{ml})\end{array}$ & $\begin{array}{c}\text { Difference } \\
(\%)\end{array}$ \\
\hline EGY1 & 75.7 & 43.2 & 32.5 \\
\hline EGY2 & 97.5 & 89.3 & 8.2 \\
\hline EGY3 & 75.8 & 48.2 & 27.6 \\
\hline EGY4 & 98.1 & 92.8 & 5.3 \\
\hline EGY7 & 93.6 & 86.5 & 7.1 \\
\hline EGY8 & 95.6 & 84.3 & 11.3 \\
\hline EGY12 & 94.7 & 82.5 & 12.2 \\
\hline EGY16 & 92.6 & 83.8 & 8.8 \\
\hline EGY20 & 89.3 & 75.5 & 13.8 \\
\hline EGY22 & 91.4 & 81.2 & 10.2 \\
\hline EGY23 & 90.5 & 82.0 & 8.5 \\
\hline EGY24 & 76.3 & 43.3 & 33.0 \\
\hline EGY26 & 93.7 & 88.3 & 5.4 \\
\hline EGY27 & 85.2 & 78.4 & 6.8 \\
\hline EGY30 & 87.8 & 77.5 & 10.3 \\
\hline EGY31 & 85.6 & 78.2 & 7.4 \\
\hline EGY34 & 76.2 & 43.1 & 33.1 \\
\hline EGY39 & 95.8 & 88.6 & 7.2 \\
\hline EGY40 & 86.4 & 72.2 & 14.2 \\
\hline EGY41 & 87.4 & 75.6 & 11.8 \\
\hline EGY47 & 92.4 & 77.3 & 15.1 \\
\hline
\end{tabular}

France). Anti-FLIP antibody (clone Dave-2) was from Adipogen (Coger, Paris, France), anti-cleaved lamin A/C Asp230 (cat\# 3596-1) from Epitomics (Abcam, Paris, France). Anti-GAPDH (clone 0411) antibody was from Santa Cruz Biotechnology (Clinisciences, Nantere, France). Anti-actin antibody (cat\# 4970) was from Cell Signaling Technology. HRP-conjugated anti-rabbit or mouse secondary antibodies were from Jackson Immuno Research (Interchim, Montluçon, France), HRP-conjugated anti-mouse IgG1-, Ig2a- and Ig2b-specific antibodies were from Southern Biotech (Clinisciences). After 3 washes in PBS-Tween 0.5\% for $10 \mathrm{~min}$, membranes were incubated for $1 \mathrm{~h}$ with the corresponding secondary antibody and washed as above. Blots were developed using the Advansta WesternBright chemiluminescence substrate according to the manufacturer's protocol (Diagomics, Blagnac, France) followed by image processing using the Bio-Rad imaging system.

\section{Results}

Cytotoxic effect of crude extracts and their sensitization to TRAIL in breast cancer cells. Forty-seven actinomycete strains were isolated from different areas of the Red Sea shore of Sharm El-Sheikh, South Sinai, Egypt. Microscopic observations revealed that both aerial and vegetative hyphae were

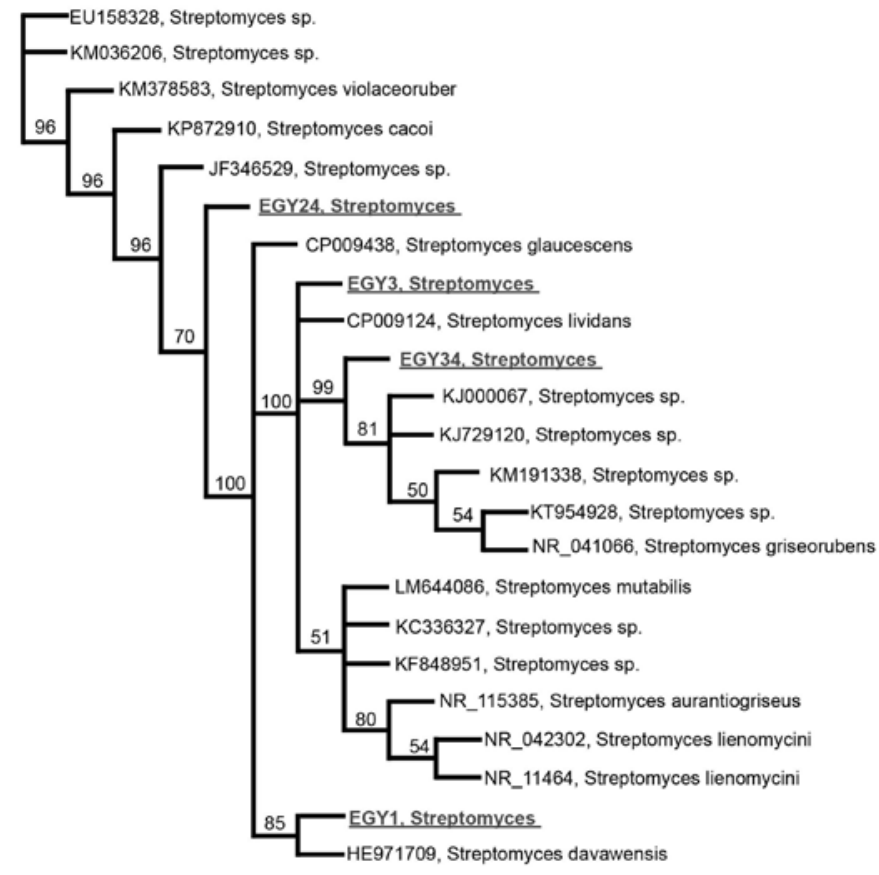

Figure 1. Phylogenetic tree for marine actinomycete strains (EGY1, EGY3, EGY24, and EGY34). The evolutionary history was inferred using the Neighbor-Joining method.

abundant and well developed. The color of aerial and substrate mycelium of 21 strains varied from yellow to red. As we are interested in pigmented secondary metabolites, the cytotoxic effect of 21 crude extracts at concentration of $0.1 \mathrm{mg} / \mathrm{ml} \mathrm{was}$ screened sequentially with and without TRAIL $(250 \mathrm{ng} / \mathrm{ml})$ in MDA-MB-231 breast cancer cells (Table I). The crude extracts that produced approximately $>20 \%$ inhibition along with TRAIL than the agent alone were selected for further investigation. Four extracts corresponding to actinomycetes EGY1, EGY3, EGY24 and EGY34 showed synergistic effects with TRAIL. Partial 16S rRNA sequence analysis revealed that the effective strains are new member of the genus Streptomyces sp., indicating $<98.2 \%$ sequence similarities (Fig. 1). The $16 \mathrm{~S}$ rRNA gene sequence of EGY1, EGY3, EGY24, and EGY34 was submitted to GeneBank with the accession numbers, KX218228, KP895876, KP792816, and KP792818, respectively.

The sensitizing effect of the crude extracts of EGY1, EGY3, EGY24 and EGY34 to TRAIL-induced apoptosis in MDA-MB-231 breast cancer cell line in both sequential and combined treatment with TRAIL was tested. Cells were incubated with various concentrations of the crude extracts $(0.04,0.1,0.2,0.3,0.6$ and $1.2 \mathrm{mg} / \mathrm{ml})$ for $24 \mathrm{~h}$. A significant concentration-dependent decrease of the cell viability of MDA-MB-231 cancer cell line was observed (Fig. 2A). When TRAIL (250 ng/ml) was sequentially added for an additional $24 \mathrm{~h}$, cell viability was significantly reduced in cells prestimulated with these crude extracts as compared to TRAIL alone. Extracts EGY1, EGY3, EGY24 and EGY34 induced a marked decrease in cell viability in the presence of TRAIL ( $250 \mathrm{ng} / \mathrm{ml}$ ), compared to TRAIL alone (Fig. 2A). Combined treatments were also assessed and cells were treated with various concentrations of the crude extracts and TRAIL ( $250 \mathrm{ng} / \mathrm{ml}$ ) for $16 \mathrm{~h}$ (Fig. 2B). Of note, TRAIL sensitizing activity of these crude extracts, even at lower concentrations, 
A
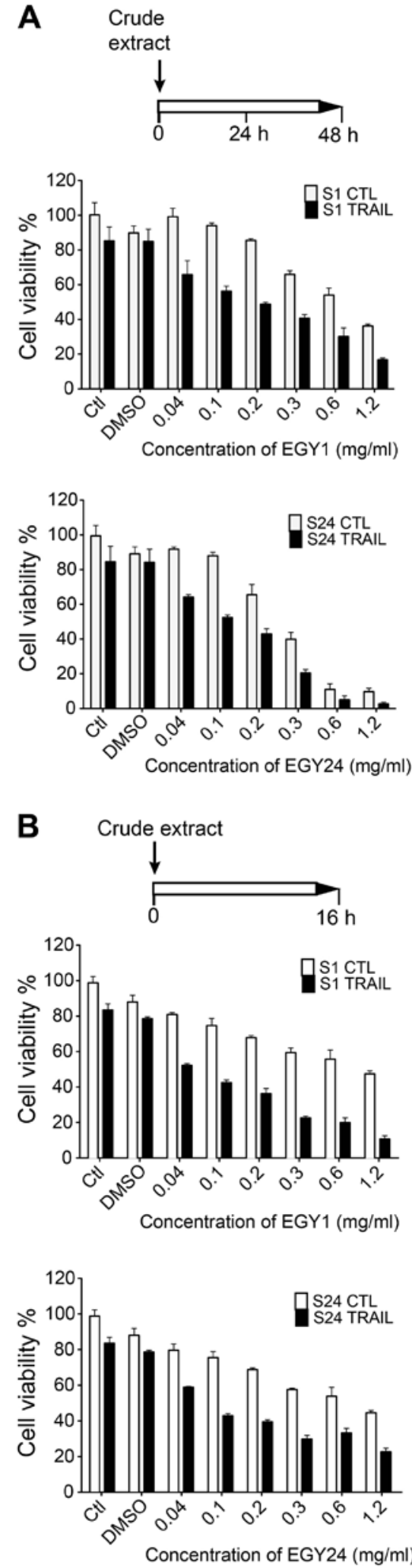
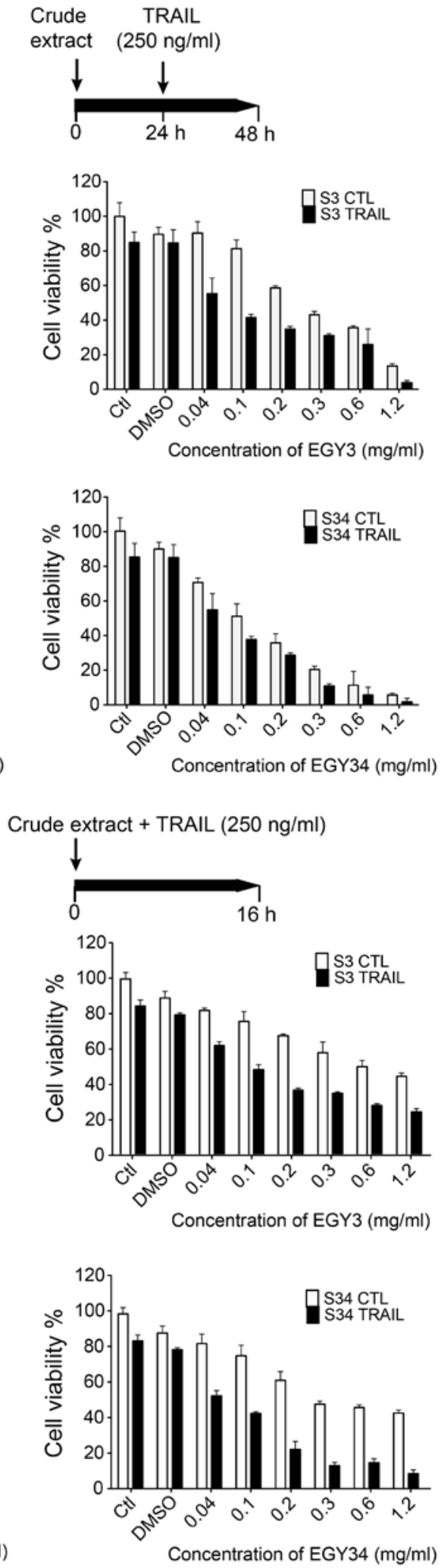

Figure 2. Effects of the identified marine actinomycete crude extracts (EGY1, EGY3, EGY24, and EGY34) on the cell viability of TRAIL-resistant MDA-MB-231 breast cancer cells with and without TRAIL. (A) Sequential treatment: cells were treated with various concentration of the crude extracts, incubated for $24 \mathrm{~h}$ and then stimulated by TRAIL $(250 \mathrm{ng} / \mathrm{ml})$ for an additional $24 \mathrm{~h}$. (B) Combined treatment: cells were treated with both crude extracts and TRAIL (250 ng/ml) and then incubated for $16 \mathrm{~h}$. Viability was evaluated by the MB method with and without TRAIL. The standard error bar represents the mean \pm SD ( $\mathrm{n}=3$ ).

was greatly enhanced. This gives a slight indication that the synergistic effect-induced by both sequential and combined treatment may be due to early apoptotic events including DISC assembly and subsequent activation of initiator caspases.
Phenotypic changes of cells pretreated with the crude extracts and after sequential stimulation with TRAIL were analyzed by microscopic investigation (Fig. 3). Pretreatment of MDA-MB-231 cells with the identified crude extracts induced 


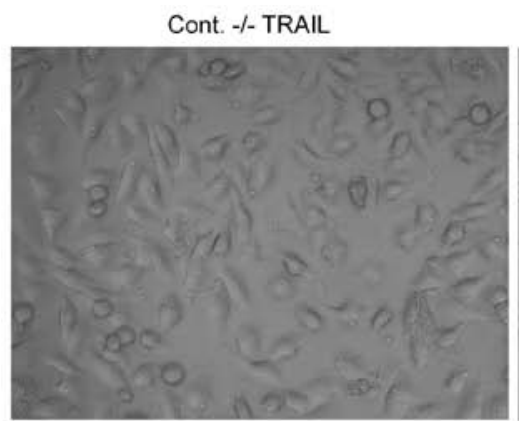

Cont. + + + TRAIL

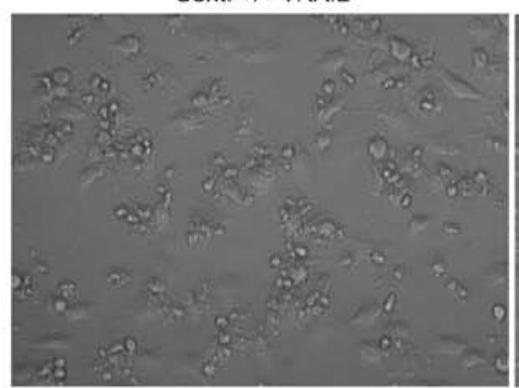

EGY1 -/- TRAIL

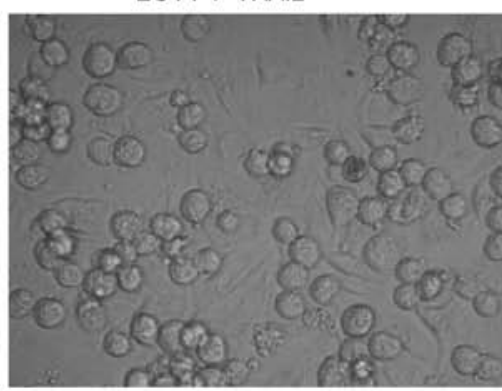

EGY $1+1+$ TRAIL

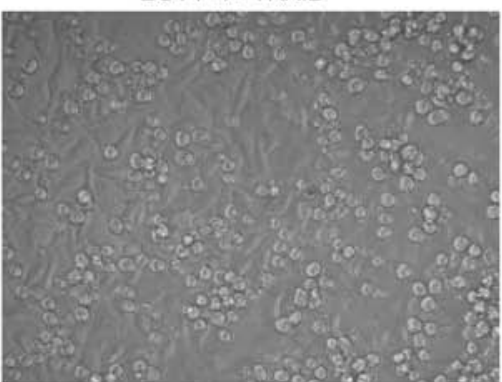

EGY3 -/- TRAIL

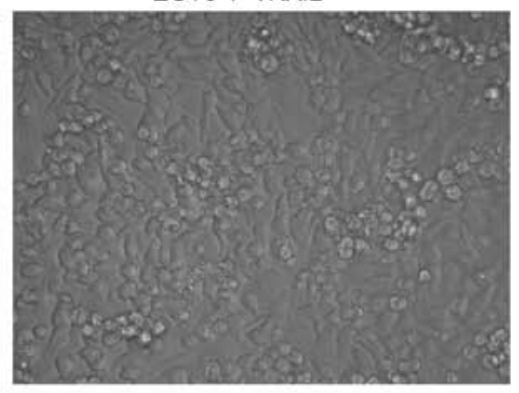

EGY3 +1+ TRAIL

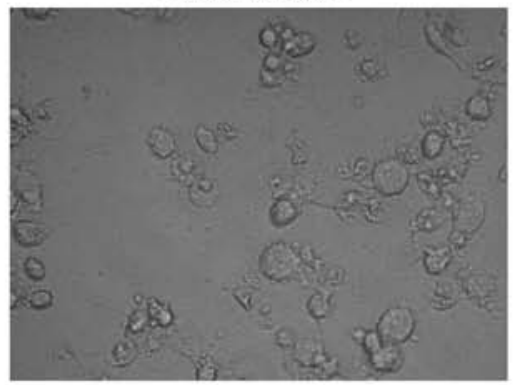

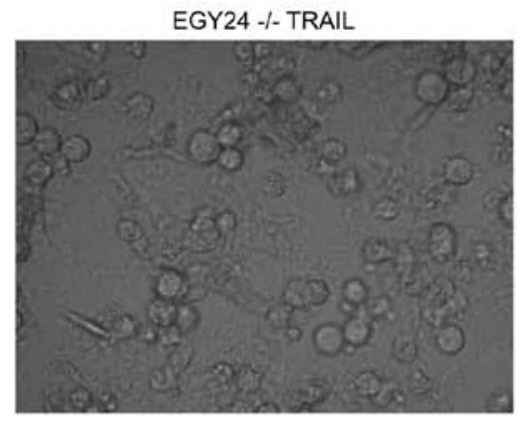

EGY24 + + TRAIL

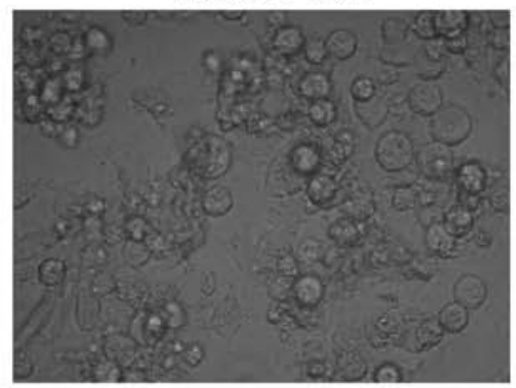

EGY34 - - TRAIL

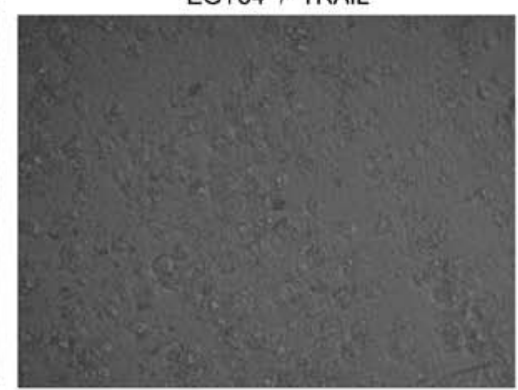

EGY34 +/+ TRAIL

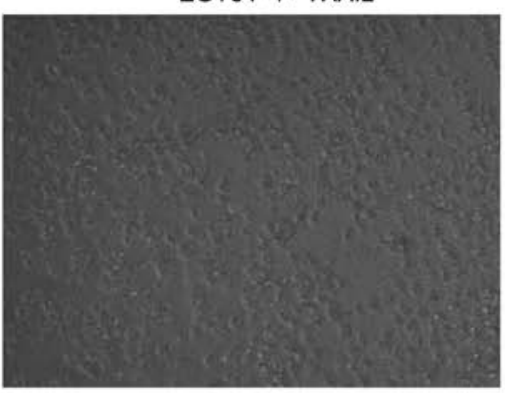

Figure 3. Phenotypic changes of MDA-MBA-231 breast cancer cells after $24 \mathrm{~h}$ of treatment with crude extracts (EGY1, EGY3, EGY24, and EGY34) with and without TRAIL. The images were captured under an inverted microscope (magnification, $x 400)$.

an early apoptosis, observed by the appearance of granulated cellular lumen, indicative of apoptotic bodies. On the other hand, cells stimulated with both crude extracts and TRAIL showed marked apoptosis in which the condensation of the genetic material in the cell center was clearly detected. In terms of selectivity, the cytotoxic effect of the crude extracts on normal mouse embryonic fibroblast (MEF) cell line was tested (Fig. 4). The crude extracts showed no cytotoxicity toward the MEF cell line. Only crude extract EGY34 induced a significant cytotoxicity at the higher concentrations (2.5 and $5.0 \mathrm{mg} / \mathrm{ml}$ ) compared to the non-treated cells.

Flow cytometric analysis of apoptosis. Annexin V and PI staining were used to measure apoptosis induced by the crude extracts alone and in combination with TRAIL (Fig. 5). Cells were treated with the crude extracts at the lowest effective concentrations and TRAIL $(250 \mathrm{ng} / \mathrm{ml})$ for $16 \mathrm{~h}$. The results correlated with the increase in the percentage of apoptosis compared to the non-stimulated cells. Flow cytometric analysis detected a slight increase in the percentage of the apoptotic cells in the control with and without TRAIL from 6.2 to $18.7 \%$ confirming the resistance of the MDA-MB-231 cells to TRAIL-induced apoptosis. The highest apoptotic effect was measured for the combined treatment of crude extracts EGY3 and EGY24 with TRAIL. These combinations increased apoptosis in MDA-MB-231 cells by approximately 5- and 2-fold, respectively. Some extracts, including EGY1, EGY24 and EGY34 induced, alone, a large amount of cell death as 


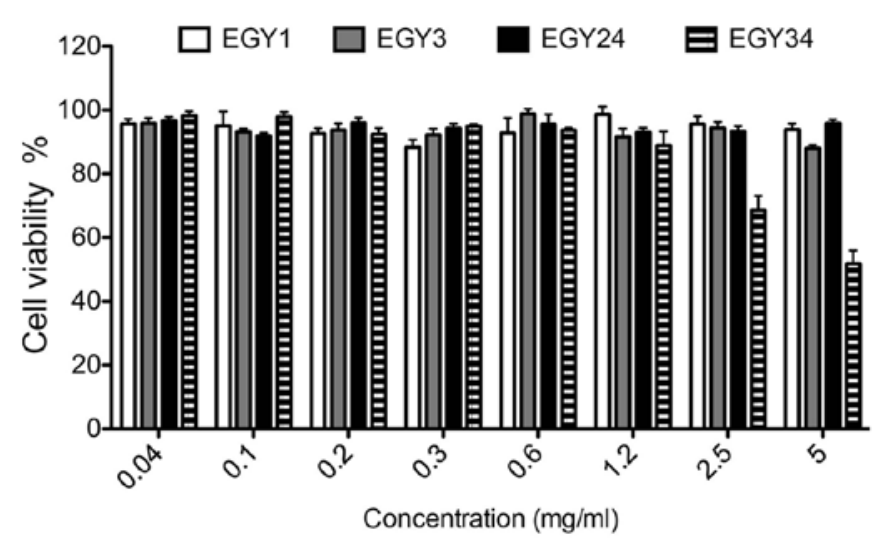

Figure 4. Effect of crude extracts from Streptomyces sp. (EGY1, EGY3, EGY24, and EGY34) on the normal mouse embryonic fibroblast (MEF) cell line. The standard error bar represents the mean $\pm \operatorname{SD}(n=3)$.

evidenced by Annexin V and PI staining (Fig. 5). Stimulation in the presence of TRAIL, however, and consistent with cell viability assays (Fig. 2), further increased cell death in resistant MDA-MB-231 cells, as evidenced with EGY3 and EGY24 extracts (Fig. 5).

Analysis of the signaling pathways triggered by the combined treatment. The molecular mechanisms by which the identified crude extracts trigger the sensitization of the breast cancer cells to TRAIL-induced cell death were explored by western blot analysis (Fig. 6). All crude extracts facilitated activation of the initiator caspase-8/-10 as a result of combined treatment with TRAIL. Consistent with the increase in Annexin V staining (Fig. 5), an increase in cleaved lamin $\mathrm{A} / \mathrm{C}$ was detected in cells stimulated with TRAIL and EGY1 or EGY34, but less so with EGY3 and EGY24. Noteworthy, some crude extracts were also able to induce an ER stress response. Likewise, as compared to serum starvation, EGY3 and EGY34, but not EGY1 and EGY24 induced by the appearance of the ER-stress sensor, binding immunoglobulin protein (BiP). These results therefore suggest that the actinomycete crude extracts identified here exhibit TRAIL-sensitizing activity, and are likely to act at least at the level of the TRAIL DISC.

\section{Discussion}

The hallmark features for initiation and progression of cancer is mainly assigned to the defect in the apoptotic signaling pathways. Despite the potent anticancer effect of TRAIL, several tumor cell lines including lung and breast cancer cells were found to possess resistance to TRAIL-induced apoptosis (35). Overcoming TRAIL-resistance by combined treatment using a chemotherapeutic agent is considered as a promising drug target in the treatment of cancer. Marine microorganisms, particularly actinomycetes still remain a rich source for the discovery of marine natural products. They are a group of bacteria, reported to produce great variety of bioactive secondary metabolites and represent a focal point in the search for novel antimicrobials and anticancer agents $(36,37)$. The cytotoxic effect of several plant and marine sponge extracts against various tumor cell lines was reported (38-43). However, the anticancer effect of crude

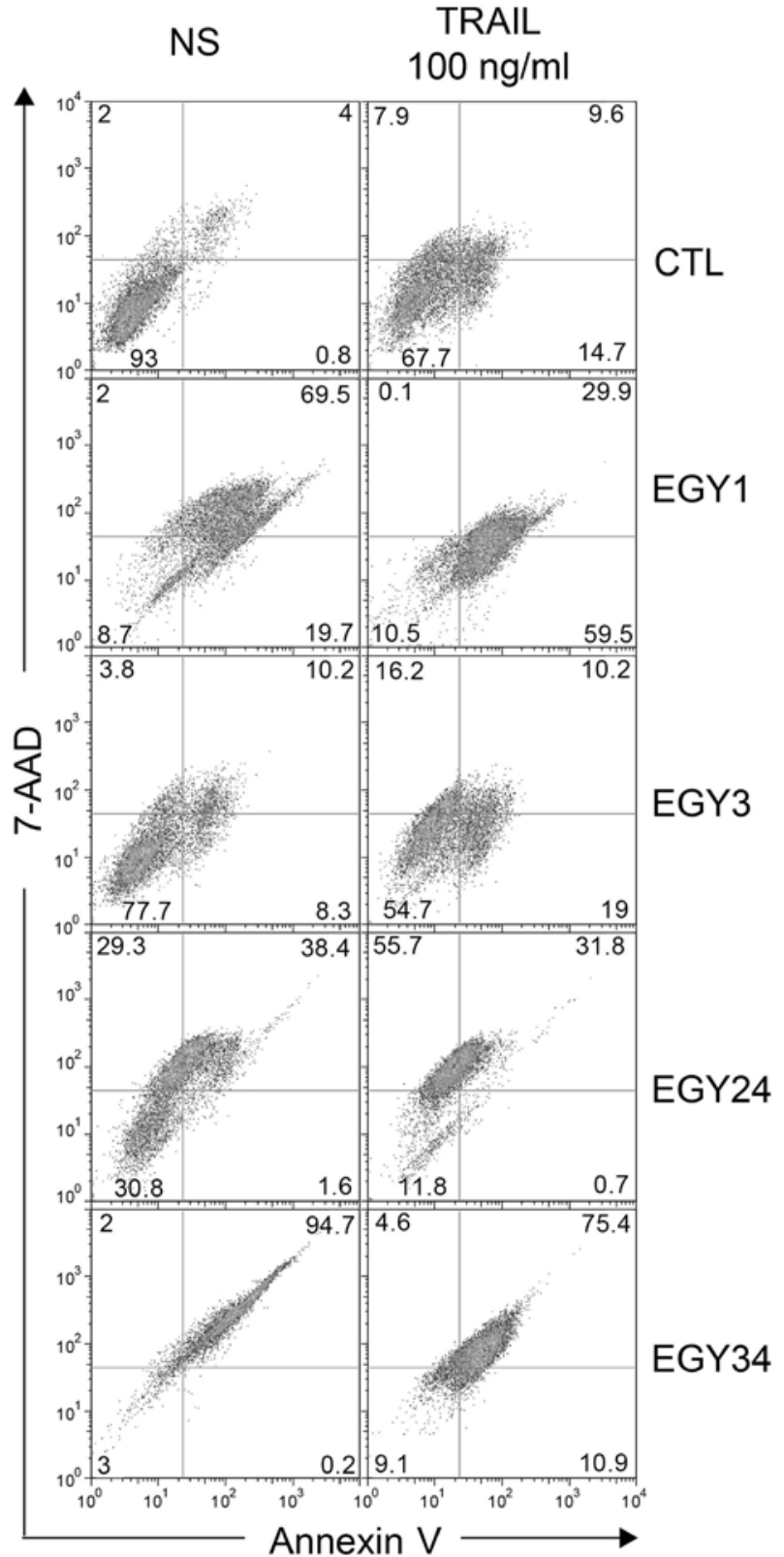

Figure 5. Flow cytometric analysis of the MDA-MB-231 breast cancer cell lines in the absence and presence of TRAIL. The cells were treated with: control (CTL); crude extract of Streptomyces sp. EGY1; crude extract of Streptomyces sp. EGY3; crude extract of Streptomyces sp. EGY24 and crude extract of Streptomyces sp. EGY34; TRAIL (250 ng/ml).

extracts isolated from marine microorganisms has not been studied yet.

In this study, 21 crude extracts of marine actinomycetes isolated from the Red Sea were found to produce yellow to red pigments based on the morphological properties. Actinomycetes are characterized by the production of various types of colored compounds (i.e. anthraquinones and phenazines) with TRAIL-resistance overcoming activity in different cancer cell lines $(25,26,28,29)$. Therefore, the TRAIL-resistance overcoming activities of the 21 crude extracts were investigated. Four crude extracts (EGY1, EGY3, EGY24, and EGY34) revealed a significant sensitizing effect to TRAIL-induced cell death. The extracts exhibited significant cytotoxic and synergistic effect by combined treatment rather than by sequential treatment 


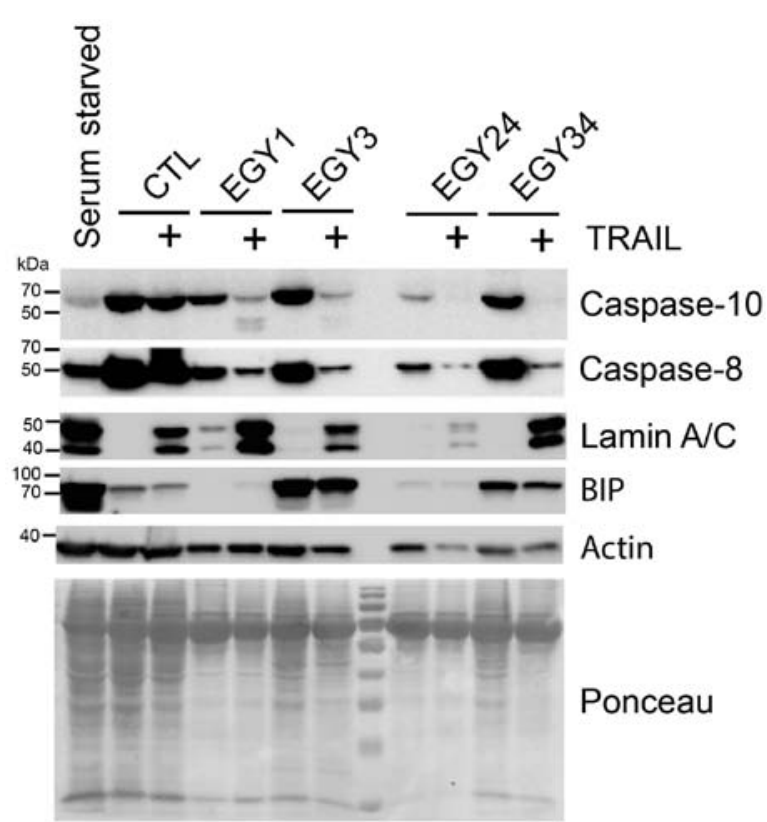

Figure 6. Western blot analysis of the signaling pathways underlying the sensitization of MDA-MB-231 breast cancer cells to TRAIL-induced apoptosis. The cells treated with crude extracts of Streptomyces sp. (EGY1, EGY3, EGY24, and EGY34) and TRAIL (250 ng/ml) for $24 \mathrm{~h}$. Fraction purity and protein loading were assessed by actin and GAPDH blotting, respectively.

with TRAIL. The significant impact of the crude extracts on the sensitization of the breast cancer cells to TRAIL-induced cell death was also confirmed by flow cytometry. It was shown that the combined treatment of the crude extracts potentially enhanced the effect of TRAIL by increasing the reduction of the cell viability. We are still in the characterization phase of the identified crude extracts represented in the purification and structural elucidation of the bioactive components as potent therapeutic agents against breast cancer.

Analyzing the molecular mechanisms for the restoration of apoptotic cell death by western blotting initially revealed two possible signaling pathways; i) stimulation of extrinsic pathway and DISC formation via activation of the initiator caspase-8/-10 and ii) stimulation of ER-stress-induced cell death. The combined treatment of MDA-MB-231 cells with the identified crude extracts and TRAIL was assumed to sensitize the cells to TRAIL-induced apoptosis by the activation of the initiator caspase-8/-10, the main components required for the assembly of DISC (44). Lamins are intermediate filament proteins lining the inner surface of the inner nuclear membrane and help maintain the structural integrity of the nucleus. Caspase-mediated proteolytic cleavage of lamins facilitates the nuclear disintegration on the apoptotic signaling pathway (45). We found that the combined treatment of MDA-MB-231 cells with EGY1 and TRAIL induces the activation of cleaved lamin A/C. Conversely, the single treatment of MDA-MB-231 with EGY3, EGY34 alone indicated an apoptotic signaling pathway-induced by ER-stress and subsequent activation of the ER-stress sensor BiP. This protein was reported to play a central role in the upregulation of DR5 thus inducing apoptosis (46).

The present study revealed the TRAIL-resistant overcoming activity of some crude extracts isolated from pigmented marine actinomycetes. The combinatorial treatment of the identified crude extracts (EGY1, EGY3, EGY24 and EGY34) with TRAIL showed a great enhancement in cell cytotoxicity at lower concentrations. Analyzing the molecular mechanism involved in the sensitization of the breast cancer cells to TRAILinduced cell death by western blotting revealed two possible apoptotic signaling pathways; i) stimulation of the extrinsic pathway via activation of both caspase-8/-10 and ii) induction of apoptosis mediated by the activation of the ER-stress sensor $\mathrm{BiP}$ as a result of the combinatorial treatment of MDA-MB-231 cells with EGY3, EGY34, and TRAIL. Our results are expected to provide new insight into the development of lead compounds against breast cancer and other types of cancer.

\section{Acknowledgements}

This work was supported by the Science and Technology Development Fund (STDF), Egypt (grant no. 4930).

\section{References}

1. Almasan A and Ashkenazi A: Apo2L/TRAIL: Apoptosis signaling, biology, and potential for cancer therapy. Cytokine Growth Factor Rev 14: 337-348, 2003.

2. Micheau O, Shirley S and Dufour F: Death receptors as targets in cancer. Br J Pharmacol 169: 1723-1744, 2013.

3. Peter ME and Krammer PH: The CD95(APO-1/Fas) DISC and beyond. Cell Death Differ 10: 26-35, 2003.

4. Kelley SK and Ashkenazi A: Targeting death receptors in cancer with Apo2L/TRAIL. Curr Opin Pharmacol 4: 333-339, 2004.

5. Falschlehner $\mathrm{C}$, Emmerich $\mathrm{CH}$, Gerlach B and Walczak $\mathrm{H}$ : TRAIL signalling: Decisions between life and death. Int $\mathrm{J}$ Biochem Cell Biol 39: 1462-1475, 2007.

6. Griffith TS and Lynch DH: TRAIL: A molecule with multiple receptors and control mechanisms. Curr Opin Immunol 10: 559-563, 1998.

7. Zhu H, Zhang L, Huang X, Davis JJ, Jacob DA, Teraishi F, Chiao $\mathrm{P}$ and Fang B: Overcoming acquired resistance to TRAIL by chemotherapeutic agents and calpain inhibitor I through distinct mechanisms. Mol Ther 9: 666-673, 2004.

8. Greco FA, Bonomi P, Crawford J, Kelly K, Oh Y, Halpern W, Lo L, Gallant G and Klein J: Phase 2 study of mapatumumab, a fully human agonistic monoclonal antibody which targets and activates the TRAIL receptor-1, in patients with advanced non-small cell lung cancer. Lung Cancer 61: 82-90, 2008.

9. Henson ES, Johnston JB and Gibson SB: The role of TRAIL death receptors in the treatment of hematological malignancies. Leuk Lymphoma 49: 27-35, 2008.

10. Humphreys RC and Halpern W: Trail receptors: Targets for cancer therapy. Adv Exp Med Biol 615: 127-158, 2008.

11. Ndozangue-Touriguine O, Sebbagh M, Mérino D, Micheau O, Bertoglio J and Bréard J: A mitochondrial block and expression of XIAP lead to resistance to TRAIL-induced apoptosis during progression to metastasis of a colon carcinoma. Oncogene 27: 6012-6022, 2008.

12. Thorburn A, Behbakht K and Ford H: TRAIL receptor-targeted therapeutics: Resistance mechanisms and strategies to avoid them. Drug Resist Updat 11: 17-24, 2008.

13. Mahalingam D, Szegezdi E, Keane M, de Jong S and Samali A: TRAIL receptor signalling and modulation: Are we on the right TRAIL? Cancer Treat Rev 35: 280-288, 2009.

14. Kaufmann T, Strasser A and Jost PJ: Fas death receptor signalling: Roles of Bid and XIAP. Cell Death Differ 19: 42-50, 2012.

15. Srivastava RK: TRAIL/Apo-2L: Mechanisms and clinical applications in cancer. Neoplasia 3: 535-546, 2001

16. Morizot A, Mérino D, Lalaoui N, Jacquemin G, Granci V, Iessi E, Lanneau D, Bouyer F, Solary E, Chauffert B, et al: Chemotherapy overcomes TRAIL-R4-mediated TRAIL resistance at the DISC level. Cell Death Differ 18: 700-711, 2011.

17. Jacquemin G, Granci V, Gallouet AS, Lalaoui N, Morlé A, Iessi E, Morizot A, Garrido C, Guillaudeux T and Micheau O: Quercetin-mediated Mcl-1 and survivin downregulation restores TRAIL-induced apoptosis in non-Hodgkin's lymphoma B cells. Haematologica 97: 38-46, 2012. 
18. Morlé A, Garrido C and Micheau O: Hyperthermia restores apoptosis induced by death receptors through aggregation-induced c-FLIP cytosolic depletion. Cell Death Dis 6: e1633, 2015.

19. Blunt JW, Copp BR, Munro MH, Northcote PT and Prinsep MR: Marine natural products. Nat Prod Rep 23: 26-78, 2006

20. Mayer AM,Rodríguez AD, Berlinck RG and Hamann MT: Marine pharmacology in 2003-4: Marine compounds with anthelmintic antibacterial, anticoagulant, antifungal, anti-inflammatory, antimalarial, antiplatelet, antiprotozoal, antituberculosis, and antiviral activities; affecting the cardiovascular, immune and nervous systems, and other miscellaneous mechanisms of action. Comp Biochem Physiol C Toxicol Pharmacol 145: 553-581, 2007.

21. Williams PG: Panning for chemical gold: Marine bacteria as a source of new therapeutics. Trends Biotechnol 27: 45-52,

22. Blunt JW, Copp BR, Hu WP, Munro MH, Northcote PT and Prinsep MR: Marine natural products. Nat Prod Rep 26: 170-244, 2009.

23. Fenical W, Sethna KM and Lloyd GK: Marine microorganisms as a developing resource for drug discovery. Pharm News 9: 489-494, 2002

24. Abdelfattah MS: A new bioactive aminophenoxazinone alkaloid from a marine-derived actinomycete. Nat Prod Res 27: 2126-2131, 2013.

25. Abdelfattah MS, Ishikawa N, Karmakar UK, Yamaku K and Ishibashi M: New phenazine analogues from Streptomyces sp. IFM 11694 with TRAIL resistance-overcoming activities. J Antibiot (Tokyo) 69: 446-450, 2016.

26. Abdelfattah MS, Toume K and Ishibashi M: Yoropyrazone, a new naphthopyridazone alkaloid isolated from Streptomyces sp. IFM 11307 and evaluation of its TRAIL resistance-overcoming activity. J Antibiot (Tokyo) 65: 245-248, 2012.

27. Abdelfattah MS, Ishikawa N, Karmakar UK and Ishibashi M: Sulfotanone, a new alkyl sulfonic acid derivative from Streptomyces sp. IFM 11694 with TRAIL resistance-overcoming activity. J Nat Med 70: 266-270, 2016.

28. Abdelfattah MS, Kazufumi T and Ishibashi M: New pyranonaphthoquinones and a phenazine alkaloid isolated from Streptomyces sp. IFM 11307 with TRAIL resistance-overcoming activity. J Antibiot (Tokyo) 64: 729-734, 2011.

29. Abdelfattah MS, Kazufumi T and Ishibashi M: Izumiphenazines A-C: Isolation and structure elucidation of phenazine derivatives from Streptomyces sp. IFM 11204. J Nat Prod 73 1999-2002, 2010.

30. Elmallah MIY and Micheau O: Marine drugs regulating apoptosis induced by tumor necrosis factor-related apoptosisinducing ligand (TRAIL). Mar Drugs 13: 6884-6909, 2015.

31. Hayakawa $M$ and Nonomura H: Humic acid-vitamin agar, a new medium for the selective isolation of soil actinomycetes. J Ferment Technol 65: 501-509, 1987.

32. Kuester E and Williams ST: Selection of media for the isolation of streptomycetes. Nature 202: 928-929, 1964.
33. Kieser T, Bibb MJ, Buttner MJ, Chater KF and Hopwood DA Practical Streptomyces Genetics. 2nd edition. The John Innes Center Foundation, Norwich, 2000.

34. Abdelfattah MS,Elmallah MIY,Hawas UW,Abou El-KassemaLT and Eid MAG: Isolation and characterization of marine-derived actinomycetes with cytotoxic activity from the Red Sea coast. Asian Pac J Trop Biomed 6: 651-657, 2016.

35. LeBlanc HN and Ashkenazi A: Apo2L/TRAIL and its death and decoy receptors. Cell Death Differ 10: 66-75, 2003.

36. Takahashi Y and Omura S: Isolation of new actinomycete strains for the screening of new bioactive compounds. J Gen Appl Microbiol 49: 141-154, 2003.

37. Blunt JW, Copp BR, Hu WP, Munro MH, Northcote PT and Prinsep MR: Marine natural products. Nat Prod Rep 24: 31-86, 2007.

38. Van Slambrouck S, Daniels AL, Hooten CJ, Brock SL, Jenkins AR, Ogasawara MA, Baker JM, Adkins G, Elias EM, Agustin VJ, et al: Effects of crude aqueous medicinal plant extracts on growth and invasion of breast cancer cells. Oncol Rep 17: 1487-1492, 2007

39. Ferretti C, Marengo B, De Ciucis C, Nitti M, Pronzato MA, Marinari UM, Pronzato R, Manconi R and Domenicotti C: Effects of Agelas oroides and Petrosia ficiformis crude extracts on human neuroblastoma cell survival. Int J Oncol 30: 161-169, 2007.

40. Oliveras-Ferraros C, Fernández-Arroyo S, Vazquez-Martin A, Lozano-Sánchez J, Cufí S, Joven J, Micol V, FernándezGutiérrez A, Segura-Carretero A and Menendez JA: Crude phenolic extracts from extra virgin olive oil circumvent de novo breast cancer resistance to HER1/HER2-targeting drugs by inducing GADD45-sensed cellular stress, G2/M arrest and hyperacetylation of Histone H3. Int J Oncol 38: 1533-1547, 2011.

41. Szliszka E, Zydowicz G, Janoszka B, Dobosz C, KowalczykZiomek $\mathrm{G}$ and Krol W: Ethanolic extract of Brazilian green propolis sensitizes prostate cancer cells to TRAIL-induced apoptosis. Int J Oncol 38: 941-953, 2011.

42. Abdelhamed S, Yokoyama S, Hafiyani L, Kalauni SK, Hayakawa Y, Awale S and Saiki I: Identification of plant extracts sensitizing breast cancer cells to TRAIL. Oncol Rep 29: 1991-1998, 2013

43. Lee YS, Lee DG, Lee JY, Kim TR, Hong SS, Kwon SW and Kim YS: A formulated red ginseng extract upregulates CHOP and increases TRAIL-mediated cytotoxicity in human hepatocellular carcinoma cells. Int J Oncol 43: 591-599, 2013.

44. Thorburn A: Death receptor-induced cell killing. Cell Signal 16: 139-144, 2004

45. Rao L, Perez D and White E: Lamin proteolysis facilitates nuclear events during apoptosis. J Cell Biol 135: 1441-1455, 1996.

46. Sano R and Reed JC: ER stress-induced cell death mechanisms. Biochim Biophys Acta 1833: 3460-3470, 2013. 